\title{
Investigation of The Awareness Level in Malaysia's Manufacturing Industries on the Implementation of Industry 4.0
}

\author{
E., Mohamad ${ }^{1}$, M.S., Abd Rahman², A.A., Abdul Rahman"1, \\ N. Mohamad ${ }^{1}$, N.A. A., Nor Azlan ${ }^{1}$, A., Saptari ${ }^{3}$ \\ 1) Fakulti Kejuruteraan Pembuatan, Universiti Teknikal Malaysia Melaka \\ Hang Tuah Jaya, 76100 Durian Tunggal, Melaka, Malaysia \\ 2) Fakulti Teknologi Kejuruteraan Mekanikal dan Pembuatan, Universiti Teknikal Malaysia Melaka \\ Hang Tuah Jaya, 76100 Durian Tunggal, Melaka, Malaysia \\ 3) Faculty of Engineering, Industrial Engineering Department, President University \\ Kota Jababeka,Cikarang, Bekasi - Indonesia 17550 \\ Email: "effendi@utem.edu.my, soufhwee@utem.edu.my, azrulazwan@utem.edu.my , \\ akramin@utem.edu.my, alyaanorazlan@gmail.com, adi.saptari@president.ac.id
}

\begin{abstract}
In this study, the researchers aimed to investigate the awareness of the Malaysian manufacturing industries with regards to the implementation of the Industry 4.0 concept and also determine its levels. Different sectors of the Malaysian manufacturing sector like the Government Link Companies (GLCs), Small and Medium-scale Enterprises (SMEs), and other national or Multinational Corporations (MNCs) were included in this study. The researchers applied a survey-based research methodology and their sample size consisted of 91 Malaysian corporations. The participants in this study comprised of the managers and employees, as company representatives, and they were asked to complete the questionnaire and participate in the interview. The results of the survey showed that around $50.5 \%$ of respondents were aware and familiar with the Industry 4.0 regulations. Also, according to the survey results, the awareness regarding the Industry 4.0 regulations was mainly due to the foreign sectors including the multinational corporations like the electrical and electronic industries which contained several advanced assets and increased productivity. These results were very helpful for further research, especially for creating a future framework that could assimilate the ideas related to Industry 4.0 amongst the various other Malaysian industries belonging to the manufacturing sector.
\end{abstract}

Keywords: Industrial 4.0, Malaysian Manufacturing Industries, the Government Link Companies, Small and Medium-scale Enterprises, National Corporations and Multinational Corporations.

\section{ABSTRAK}

Studi ini bertujuan untuk mengetahui kesadaran industri manufaktur Malaysia terkait dengan penerapan konsep Industri 4.0 dan juga menentukan levelnya. Berbagai sektor manufaktur Malaysia seperti Government Link Companies (GLCS), Small and Medium-scale Enterprises (SME), dan Perusahaan Nasional atau Multinasional (MNC) lainnya dimasukkan dalam studi ini. Para peneliti menerapkan metodologi penelitian berbasis survei dan ukuran sampel mereka terdiri dari 91 perusahaan Malaysia. Partisipan dalam penelitian ini terdiri dari manajer dan karyawan, sebagai perwakilan perusahaan, dan mereka diminta untuk mengisi kuesioner dan berpartisipasi dalam wawancara. Hasil survei menunjukkan bahwa sekitar 50,5\% responden mengetahui dan mengenal regulasi Industri 4.0. Selain itu, berdasarkan hasil survei, kesadaran terhadap regulasi Industri 4.0 terutama disebabkan oleh sektor asing termasuk perusahaan multinasional seperti industri kelistrikan dan elektronik yang memiliki beberapa aset maju dan peningkatan produktivitas. Hasil ini sangat membantu untuk penelitian lebih lanjut, terutama untuk menciptakan kerangka kerja masa depan yang dapat mengasimilasi ide-ide terkait Industri 4.0 di antara berbagai industri Malaysia lainnya yang termasuk dalam sektor manufaktur.

Kata Kunci: Industri 4.0, Industri Manufaktur Malaysia, Perusahaan Hubungan Pemerintah, Usaha Kecil dan Menengah, Perusahaan Nasional dan Perusahaan Multinasional. 


\section{Introduction}

Due to the exponential rise in the digital transformation of the manufacturing sector, there has been a decline in the implementation of the traditional manufacturing processes. For coping with such a decline, the manufacturing sector has to consider the transformation and progress towards Industry 4.0. The government has spent RM210 million Industry 4WRD fund for 2019 to 2021 to support the transition and migration to Industry 4.0 has motivated the manufacturing industry in Malaysia to adopt the new concept. With that, the Malaysian government has targeted by 2025 , the manufacturing sector predicted to contribute to the national economy from RM254 billion to RM 392 billion (based on 2016 baseline) (MITI, 2017).

The development of Industry 4.0 is expected to open up new economic opportunities (Almada-Lobo, 2016). World Economy Forum (WEF) reported that Malaysia has a strong current production base and is well-positioned for the future. Figure 1 shows that Malaysia falls under the leading category of readiness for Industry 4.0. Based on this status, the researcher began to make some plans for the study conducted.

The main objective of the Industry 4.0 was to establish a flexible production model for personalizing the digital services or products, by bringing about an actual interaction between the devices, products, and the people involved in the operation (Wan et al., 2015). The researchers carried out a survey-based study for understanding the implementation of the Industry 4.0 with regards to a global point of view and for assessing the managerial awareness in the Malaysian manufacturing sector. The term "Industry 4.0" originated from a high-tech strategic project started by the German government that promoted the computerization of the manufacturing sector. Bahrin et al. (2016) stated that Industry 4.0 was based on 9 factors: system integration, automation robot, cybersecurity, Augmented Reality, loT, 3D printing, cloud system, and a big data system, as presented in Figure 2.

\section{Malaysia's Readiness for Industry 4.0}

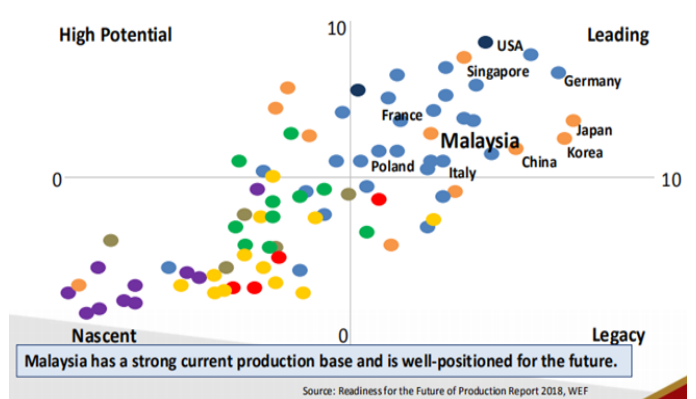

Figure 1. Malaysia's Readiness for Industry 4.0

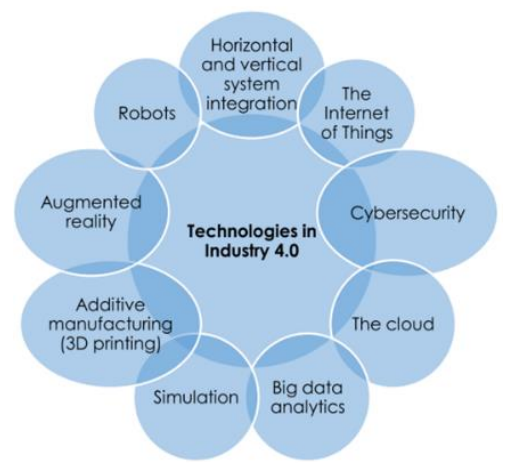

Figure 2. 9 pillars of Industry 4.0 (Bahrin et al., 2015)

\section{Methodology}

The researchers applied a structured survey-based approach by distributing questionnaires and conducting informal interviews. According to the Federal of Malaysia Manufacturers, around 2,800 manufacturing and industrial companies of different sizes were registered in Malaysia until July 2017 (Federation of Malaysia Manufacturers, 2017). The researchers distributed the questionnaires online among the various target groups, which comprised of managers and the executive employees from different industrial sectors. Some of the interviews were conducted through the telephone and the conversations were pre-recorded after seeking permission for addressing the ethical concerns and resultant dilemmas (Vouzas and Psychogios, 2007). Total respondents participated in the study were 91 . The value for the Cronbach's alpha for all the questions was 0.744 which was $>0.7$. This showed that the collected data was reliable as it had a higher internal consistency and could be used for further analysis.

\subsection{Survey Approach}

Based current status of Malaysia's readiness for Industry 4.0, the item questionnaires were developed. Therefore, there are three research questions would conclude the aims of the research. There are:

RQ 1: Levels of Implementation the Industry 4.0

RQ 2: Significance / Impacts Industry 4.0 to manufacturing sector 
RQ 3: Malaysia's Efforts towards implementing Industry 4.0

Structured survey single question has been delivered based the research questions. All the research questions are generated from the literature.

\section{Results and Discussion}

\subsection{Malaysia in the Fourth Industrial Revolution Trend Systems and Technologies with Regards to Industry 4.0}

Text Germany introduced the 4th industrial revolution, followed by the other countries. For instance, France introduced the concept of Industrie du Futur, USA introduced the concept of Smart Manufacturing Leadership Coalition (SMLC), UK proposed the Digital Transformation Plan, while Japan implemented the Industrial Value Chain Initiative (IVLE), and finally, Singapore introduced the concept of Industry 4.0 in the Jurong Island Ecoindustrial Park (Pan et al., 2015). Furthermore, some other developing countries like India, China, and Thailand have also begun implementing this concept in their manufacturing sectors, as described in Figure 3. Such a transformation in the industrial sector has been implemented by incorporating programs like 'Made in India' and 'Made in China' (Wolf et al., 2011; Bennett, 2014; Gilchrist, 2016). These programs boost competitiveness amongst the industries and help them compete against other countries. The employment, of regular internetestablished procedures, can facilitate interaction, between the linked systems, for data analysis and failure prediction, as well as for the system's configuration. Industry 4.0, the fourth surge in technological progression, can be described as a conversion derived through nine advances in technology. These advances are illustrated in Figure 1. While introducing the 11th Malaysian Plan, the Prime Minister stated that a 5-year comprehensive plan would be initiated from 2016 to 2020, which would help the country increase its productivity and decrease the inputs from the labour or capital (Unknown, 2016). Though Malaysia has been previously involved with the Proton automation and robotics, the Industry 4.0 concept in the country was mainly inspired by the many foreign organizations like the German industrial robots' manufacturer, KUKA and the Swedish-Swiss multinational organization, $\mathrm{ABB}$, which specialized in the automation and the robotics field (Bahrin et al., 2016). It is interesting to note the current Malaysian position was comparable to that of the countries described above. In the Astro Awani News, Rubaneswaran (2017), who is the Executive Leader of the KnowledgeCom Corporation, Sdn Bhd, stated that a majority of the Malaysian industries were in their labour-based Industry 2.0 levels, and these industries had to progress to reach an Industry 4.0 level.

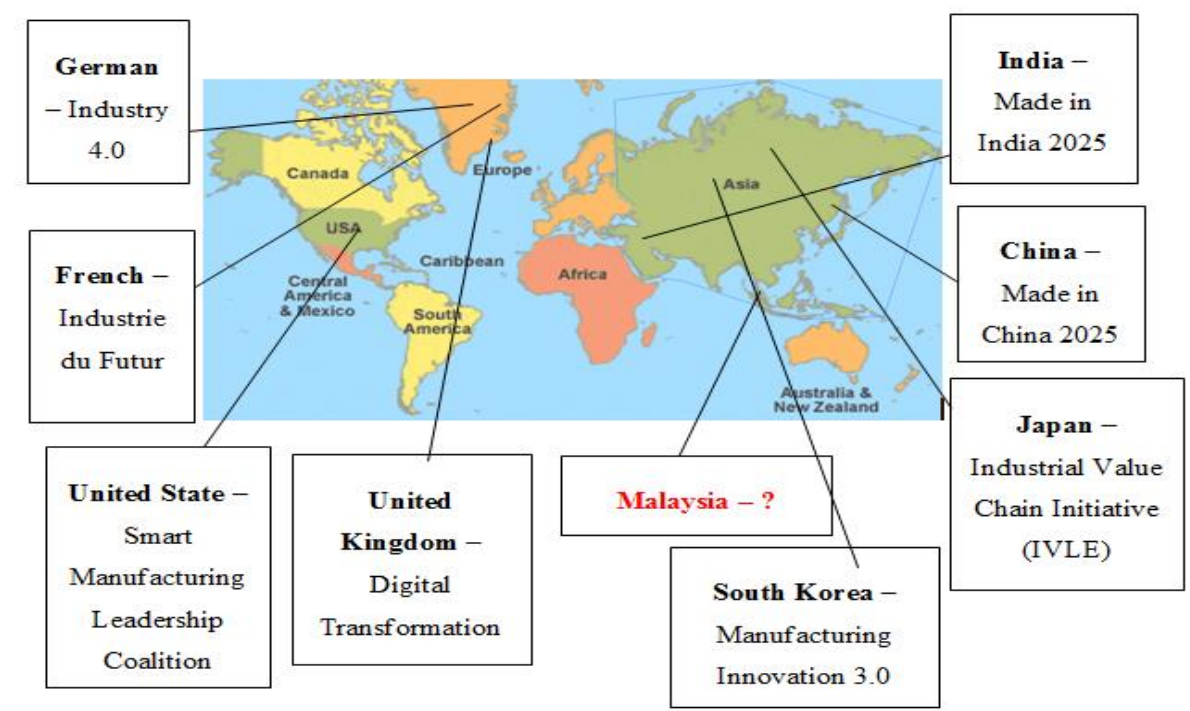

Figure 3. Countries Involved in the Future Digitalization of the Industrial Sector

In the past, Malaysia was a leading industrial country; however, currently, many of the neighboring countries have been more successful in bridging the gap between the Industry 3.0 to the Industry 4.0. If implemented, the Industry 4.0 status could easily boost the global competitive rank of the Malaysian corporations; however, this can only be possible if these companies incorporate digital technologies in their industrial sectors. Digitalization of the manufacturing sector helps in improving the competitiveness of the company, opens many novel routes and opportunities, increases the investments and risks, ensures a better cooperation between the employees and management, defines resource-related problems, identifies the key potential for each business 
segment, and also facilitates the development of novel manufacturing technologies (Schlechtendahl et al., 2014).

\subsection{Survey Findings and Analysis}

\subsubsection{Demographic Data and Analysis}

Here, the researchers investigated 91 respondents from different industrial sectors. Out of these 91,71 answered the questionnaires, while the remaining 20 answered through the semi-structured interviews conducted. In Figure 4, the researchers have described the different industrial sectors and the companies which were represented by the respondents in this study. It can be seen that a maximum number of respondents represented the electrical and the electronic sectors $(42.9 \%)$, which was followed by the plastic, rubber, and textile industries $(24.20 \%)$, the automotive and aerospace sector $(9.9 \%)$, the metallurgy and the oil and gas sector $(4.4 \%)$, food and beverage industries $(2.2 \%)$ and finally the transportation, agriculture and the forest sector (1.1\%). According to the Ministry of International Trade and Industry (MITI), the different Malaysian sub-sectors were in tandem with the 4th industrial revolution like the automobile, electrical and electronics, and the aerospace industries (Star, 2017).

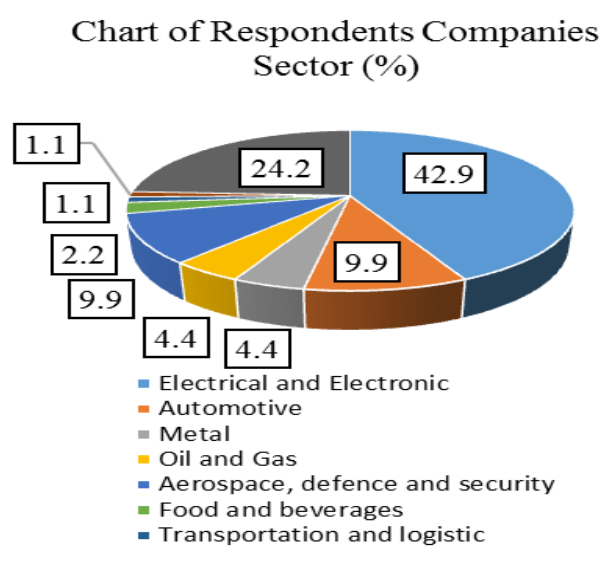

Figure 4. A total of 91 respondents from different industries were selected in this study
Chart for Type of Respondents Companies

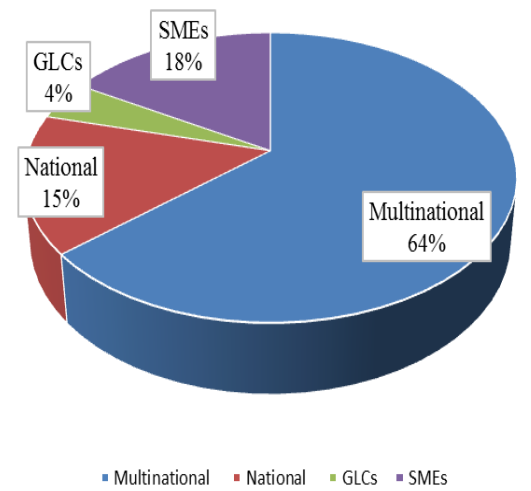

Figure 5. A pie chart describing the respondent's type of companies

Depending on the type of the organization, Figure 5 showed that a majority of the respondents belonged to the multinational companies (64\%). As shown earlier, the foreign organizations like KUKA and ABB have greatly influenced the automation and robotics sector (Bahrin et al., 2016). The Malaysian SMEs were seen to majorly favour the village-based organizations (Economic Planning Unit Prime's Minister Department, 2017) since they were not forceful. Many SMEs are unable to pursue the Industry 4.0 levels aggressively as they utilize their general abilities. $18 \%$ of the respondents represented the SMEs, while $15 \%$ represented the national companies. Finally, $4.4 \%$ of the respondents represented the GLCs. It can be seen that all the larger corporations, including the MNCs, consider the Industry 4.0 concept to be highly significant (Bahrin et al., 2016), while the SMEs do not think that this concept is relevant to their progress.

In this study, the researchers mainly targeted the executive level employees who specialized in the IT and the production departments. As shown in Figure 6, a majority of the respondents were engineers (39\%), followed by the other executive positions (21\%), like the Chief Executive Officer (CEO), Heads of departments like IT, Plant, R\&D Heads, System Integrators, and Consultants, followed by General Managers (15\%), Senior Engineers (9\%) and final the Company Directors (7\%). The different perspectives were based on factors like educational background, age, and the managerial experience level (Vouzas and Psychogios, 2007). Some of the factors were also related to the companies themselves, which could change their perspectives regarding the Industry 4.0 levels in the Malaysian manufacturing sector like the size-specific domains which they operated within. Furthermore, the respondent's position in the company affected their attitude and their exposure towards the Industry 4.0 concept, as they were constantly exposed to the programs and the seminars conducted by the private agencies and the Malaysian government. 


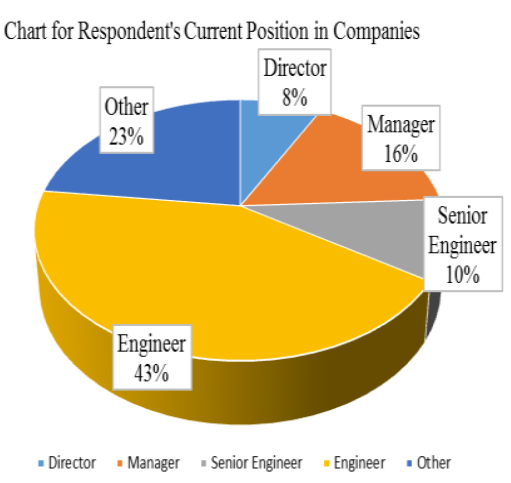

Figure 6. A pie chart describing the respondent's type of companies

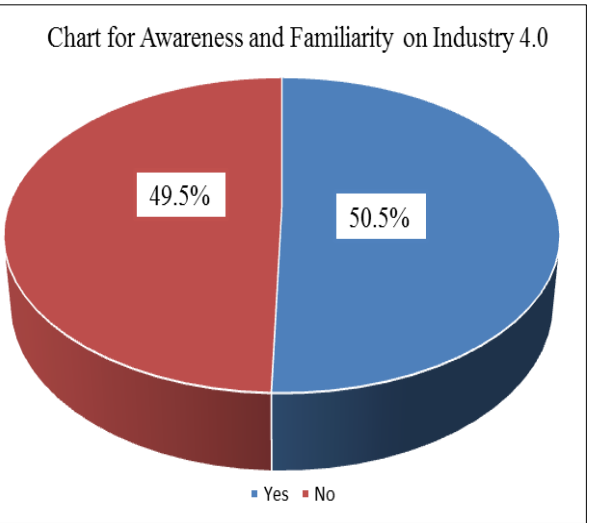

Figure 7. A pie chart describing the respondent's type of companies

\subsubsection{Managerial Awareness Towards Industry 4.0 Concept}

In this section, the researchers have discussed, analyzed, and investigated the awareness levels of the managers from the Malaysian manufacturing sector towards Industry 4.0 from a global perspective. They applied the survey-based descriptive statistics for assessing and describing the factors responsible for implementing Industry 4.0. In Figure 7, the researchers have presented the results depicting the managerial awareness and the familiarity with the Industry 4.0 concept. It was seen that around $50.5 \%$ of respondents who were aware of the Industry 4.0 concept, belonged to the multinational and foreign-owned corporations. This was because such companies possessed assets related to the current technologies like patents and advanced R\&D activities (Ramstetter and Shahrazat, 2009).

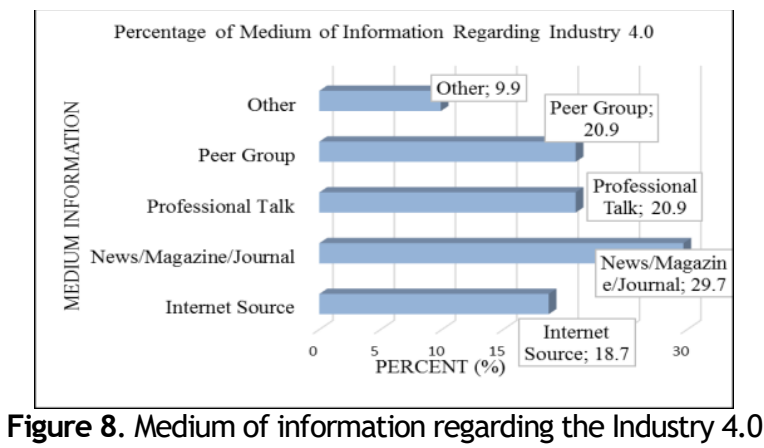

In Figure 8, the researchers have described the different information sources that could be accessed by the respondents for obtaining more Industry 4.0 information. It was seen that out of the 46 respondents who were familiar with this concept, about $29.7 \%$ obtained their information from the News/magazines/ journals, followed by the Professional talks (20.9\%), peers (20.9\%), internet sources (18.7\%), and other resources $(9.9 \%)$. Many of the private and the government-owned agencies like the Malaysia Investment Development Authority (MIDA) and the Ministry of International Trade and Industry (MITI) conducted several seminars, programs, and workshops for exposing the employees and managers to the Industry 4.0 concept. For achieving all the objectives of the Industry 4.0 revolution, the organization has to employ the best strategies. Hence, some of the criteria involved in determining the interactive strategies for the Industry 4.0 concept include the implementation status strategies, review of the strategies through an indicator system, an investment in the associated activities, implementation of the technology, and the innovation management (Goericke et al., 2016). Based on the respondents' perspectives, the researchers have highlighted the levels of the strategies regarding the implementation of the Industry 4.0 concept in Figure 9. A majority of the participants $(29.7 \%)$ have stated that their companies were in the initial or planning stages of the Industry 4.0 implementation program. In order to successfully implement the Industry 4.0 concept, the best strategy that can be applied includes the initiation of a transformation process in the company culture, shifting from the control and automation sector towards the actual cloud-based services and interoperability that requires leadership and more sponsors (Kagermann et al., 2013). Furthermore, some respondents (20.9\%) stated that their companies were in the elementary or intermediate stage of implementing the Industry 4.0 concept and had begun their transformation process. Finally, $18.7 \%$ of the participants stated that their companies did not apply any strategy for implementing the Industry 4.0 concept. In one study, the researcher (Fiwaremexico, 2017) had mentioned that there was a lack of a national long-term strategy, which could be used for increasing the awareness amongst the companies towards such trends. 


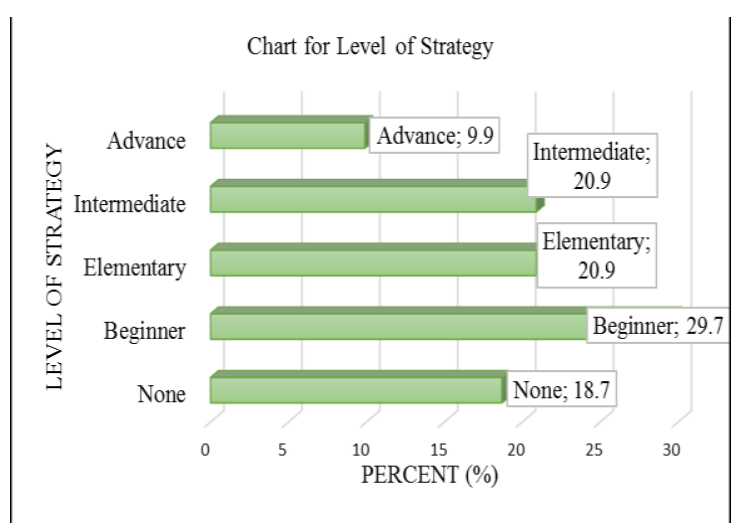

Figure 9. Strategy levels for the Industry 4.0

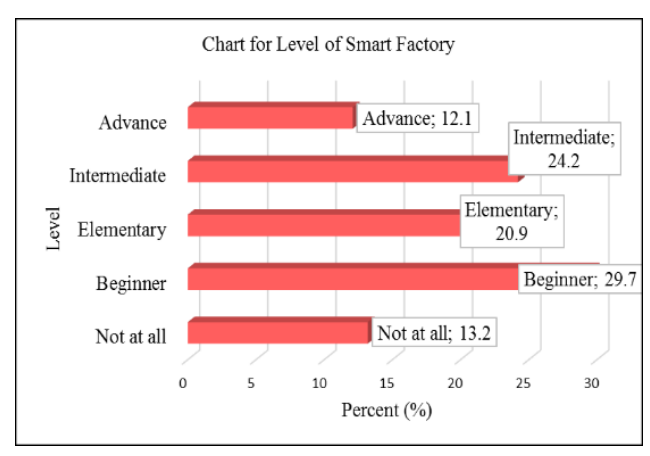

Figure 10. Levels of the Implementation of Smart Factory

Smart factories create an environment wherein the machinery and the devices are improved through the mechanization concepts and through self-advancement and require no human intervention. A successful Industry 4.0 implementation allows a disseminated and highly computerized production (Goericke et al., 2017). The company's progress towards becoming a Smart factory could be determined based on their infrastructural equipment, digital modelling, data usage, and their IT systems. As manufacturers demand the greater connectivity and interaction of Industry 4.0 with support by IT in their system, the changes will impact the current work environment. The growing interconnectivity of machines, products, parts, and humans will also require new international standards that define the interaction of these elements in the digital factory of the future (Rüßmann et al., 2015). To create the right ecosystem for Industry 4.0 technologies to be adopted and to nurture innovations, a new target was delivered. Malaysia Industry 4WRD was put a target on the global innovation index (GII) ranking as national goals. The Gll helps create an environment that evaluates innovation factors continuously. The new target for Gll is the top 30. Now, Malaysia in 33rd rank.

The companies can become a smart factory if the employees monitor the systems and combine the physical incoming data like the tool position, and the virtual data like simulation models and electronic documents, while carrying out their tasks (Herman et al., 2016). According to the survey, 12.1\% of the participants stated that their companies were at an advanced level with regards to the implementation of a smart factory concept, while $24.2 \%$ of respondents stated that their companies were at the intermediate level. $20.9 \%$ of the respondents stated that their companies were still at the elementary level with regards to the smart factory concept. Finally, $13.2 \%$ of the participants stated that their companies did not apply such a concept, due to a lack in the company infrastructure (Fiwaremexico, 2017), i.e., lack in the budget of an innovative environment (Figure 10).

Figure 11 shows the implementation levels of the smart operations within the companies. $11 \%$ of the participants stated that their companies had fully implemented the smart operations which included IT security, cloud usage, information sharing and autonomous processes (Goericke, 2017). According to the research conducted by the MIT Sloan (United Parcel Service America, 2016), the companies that had fully transformed and implemented this concept showed a $26 \%$ increase in profits. $60.4 \%$ respondents stated that their companies had begun applying the smart operations to a certain extent. A lack of technological infrastructure is a major challenge that affects the implementation of this concept (Fiwaremexico, 2017). Finally, 28.6\% respondents stated that their companies did not apply the smart operations. The company ecosystem is a major factor which affects the application of the smart operation concept, wherein the intention of the companies towards increasing the usage of the external parties for all the process domains is affected by a skill shortage (United Parcel Service America, 2016). Tremendous cooperation amongst the technology (integration), skilled workers (indicative of industry knowledge) and the finances (risk alleviation) is required for implementing this concept (United Parcel Service America, 2016). Smart products are equipped with the various ICT components for data collection based on their condition. These products collect the data, determine the path through the production line and connect with the complete system, autonomously in realtime (Georicke, 2017). 


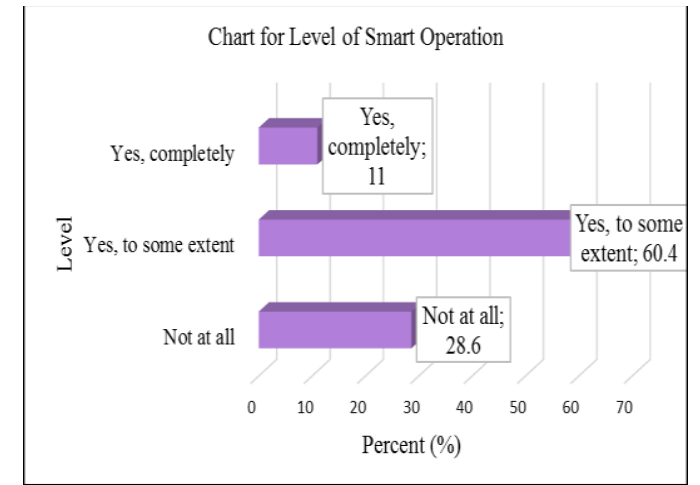

Figure 11. Levels of Implementation of Smart Operation

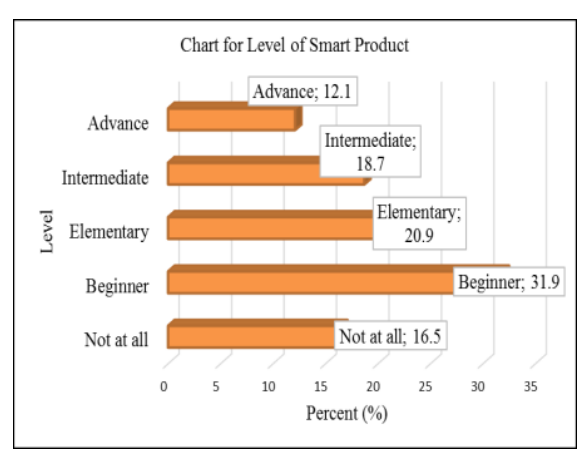

Figure 12. Levels of Implementation of the Smart Products

In Figure 12, the researchers have assessed the replies of the participants with regards to the smart products' implementation in their organizations. Around $12.1 \%$ of respondents stated that their companies were at an advanced level with regards to the implementation of smart products. On the other hand, some respondents $(18.7 \%)$ stated that their companies were at an intermediate level with regards to the implementation of the smart products. They required additional hardware, software, data storage, microprocessors, sensors, and network components that were connected to each other in the complex system, and hence experts were needed for monitoring and controlling the system (International Controller Association, 2015). 20.9\% of participants stated that their companies were at an elementary level with regards to the implementation of the smart products, indicating that they required IT assets, a competitive environment, and experts for assessing their current capacities and operational models.

These companies were worried whether they could implement smart products based on their current system (Gates, 2017). 31.9\% of the participants stated that their companies were still in the planning or initial stages of implementing smart products. Here, the readiness with regards to the smart products has to be determined based on the ICT add-on functionalities of such products and the final extent to which the data from the usage stage was analyzed (Gates, 2017). Finally, $16.5 \%$ of the participants stated that their companies had no plans to implement the smart products. According to the survey carried out by the Industrial Manufacturing, Aerospace and Defense, KPMG, USA, the manufacturers were afraid to integrate the smart products within their Industry 4.0 environment, and instead they used to re-evaluate the relationship between the products and the resultant profits while using the Industry 4.0 concept as their lens (Gates, 2017).

In Figure 13, the researchers presented the data related to the significance of the data-driven services utilized in the different companies. $29.7 \%$ respondents stated that their companies believed that the data usage and its analysis were vital for their productivity. Use of such data-driven services in the marketing sector involves obtaining information and optimizing the alternatives through any of the conducted activities (Kumar et al., 2013). 46.2\% respondents asserted that their companies believed that the data usage and analytical services were vital for their productivity since such services were perfectly aligned with their future business model and the implementation of these services would benefit their consumers (Goericke et al., 2017). With better technologies being used, the machine data and its functionality would increase the usage of the cloud services that would further enable the implementation of better data-driven services for a production system. The Industry 4.0 would require a high data sharing amongst the different sites and beyond company boundaries (Bahrin et al., 2016). 15.4\% respondents stated that data usage and its analysis was moderately important for improving the company productivity. They stated that this concept should be explained to the employees by encouraging discussions about the advantages of using the concept recommendations, assessing the Rate of Investment (ROI) for any technological investment, decreasing the perceived complexity of the system used and establishing better business outcomes after investing and use (Kumar et al., 2013). 7.7\% respondents stated that their companies believed that this concept would slightly improve their productivity. These companies believed that the major challenge involved ensuring an analytical capacity where the IT infrastructure could collect data, storage and analysis of a large amount of collected data with regards to the terabytes of data that exists currently. Furthermore, all the employees had to be trained with respect to the usage and monitoring of this data-driven concept for improving the company productivity (Kumar et al., 2013). 


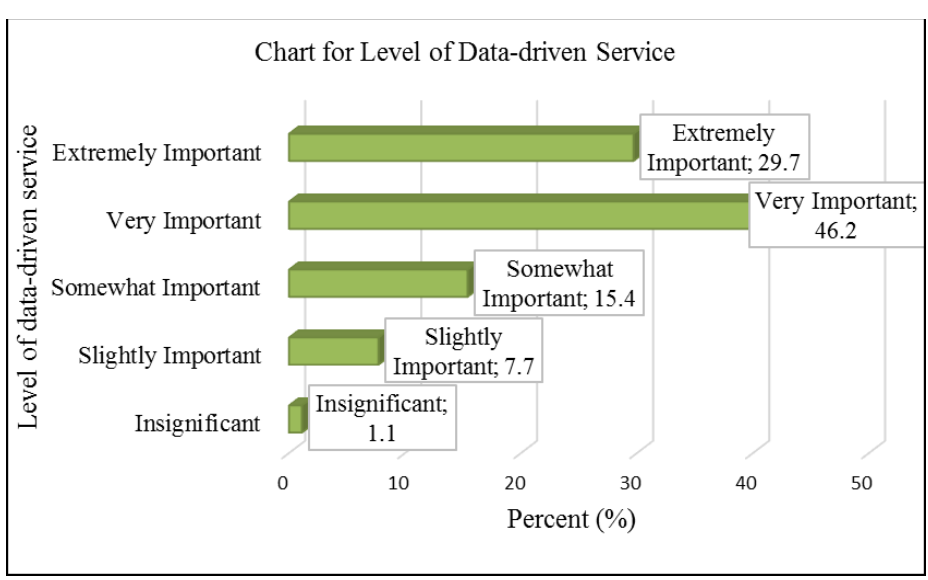

Figure 13. Significance of the Data-driven Services

Finally, the remaining $1.1 \%$ of the participants stated that this type of data usage or analysis was not helpful for increasing their company productivity. Here, these companies have not understood the relevance of implementing an organization culture and ethics for embracing the data usage, analytics and need to obtain more insights into this concept (Kumar et al., 2013).

With an increase in the number of employees in the loT and a higher financial and political interest leads to an increasing number of attacks on the production infrastructure of the Industry 4.0, which has highlighted the need to install a proper cybersecurity system (Herman et al., 2016).

In Figure 14, the researchers have presented the sophistication level of the IT security systems used in different companies. $11 \%$ respondents stated that their companies had installed extremely secure and sophisticated IT security systems. Klimoski (2016) stated that manufacturers have to follow 4 steps for ensuring cybersecurity: ensure that their employees are aware of the cyber risks, raise attention about the problem of cybersecurity with the board, install a response plan for the cyber-breach incidents, and monitor the probable cyber threats by analyzing the business Key Performance Indicators (KPIs). 33\% respondents claimed that their companies had installed very sophisticated IT security systems. From an operational point of view, such a sophisticated Incident Command System (ICS) environment would allow the engineers to operate the unmanned sites and maintain high efficiency and control over the resources.

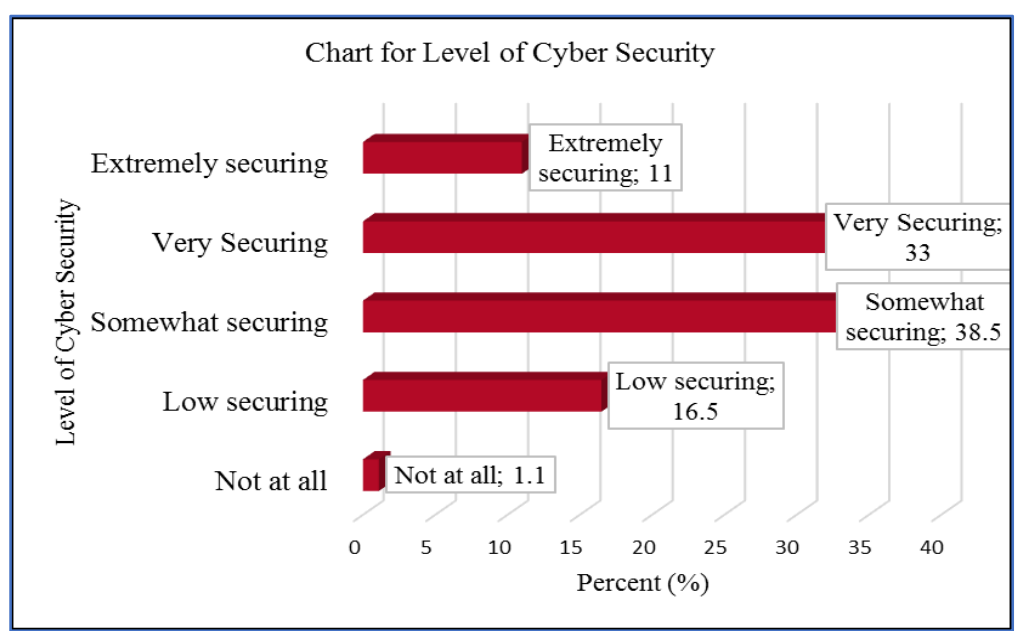

Figure 14. Sophistication of the company IT Security Systems

This could be done by implementing the enterprise resource planning system with a supervisory control and installing proper data acquisition systems (Waslo et al., 2017). 38.5\% respondents asserted that their companies had installed moderately sophisticated IT security systems. Due to increasing cybersecurity issues, many companies are not willing to use the services of the foreign IT network providers (Wee et al., 2015). USA and German companies carry out IT outsourcing and willingly outsource and use the servers across the globe. Cybersecurity must be an essential component of any strategy and must be considered from the initiation of the program. Industrial companies believed that they faced an operational disruption due to the breach of their cybersecurity. They were also concerned about an unauthorized data extraction and liability risks that could occur due to data loss. Though it is difficult to completely trust the digital services, these services are 
transparent, legitimate, and effective. $16.5 \%$ respondents stated that their companies had installed less secure IT systems as they could not obtain highly skilled people for designing and implementing secure, resilient, and alert security systems.

It is difficult to employ skilled people for designing and installing secure, durable, and alert security systems (Waslo et al., 2017). 1\% respondents stated that their companies had not installed any IT security systems. According to the Deloitte-MAPI study, 1/3rd of the manufacturers do not carry out cyber risk assessments for the industrial control systems on the production floors (Waslo et al., 2017). This could be due to a lack of technological infrastructure, the absence of a long-term strategy for implementing the Industry 4.0 guidelines and lack of an innovative environment (Fiwaremexico, 2017).

There is no clear data with regards to the talent requirement, availability of skilled employees, the time needed for sourcing talent, type of skilled workers needed, and the number of workers needed for implementing the Industry 4.0 guidelines in the Malaysian industries. In Figure 15, the researcher has presented the existence of the skilled workers in the companies. $17.6 \%$ respondents stated that their company had an adequate number of skilled and expert workers. The management must recognize the proper talent for handling their IT systems, use a data-driven strategy as their priority and make proper investments in order to make the right decisions for supporting and making the system more effective (Kumar et al., 2013). Some of the creative operations like R\&D and strategic planning need highly skilled workers for innovating and implementing Industry 4.0 guidelines (Schlaepfer, 2015). 64.8\% respondents asserted that their companies had an inadequate number of skilled workers. The 4 th industrial revolution would introduce many new challenges (Schlaepfer, 2015). Hence, the creativity standards must be established if the top management finds these challenges difficult as they have to exploit the latest novel business opportunities presented by the Industry 4.0 since the daily working of the business can become challenging (Schlaepfer, 2015).

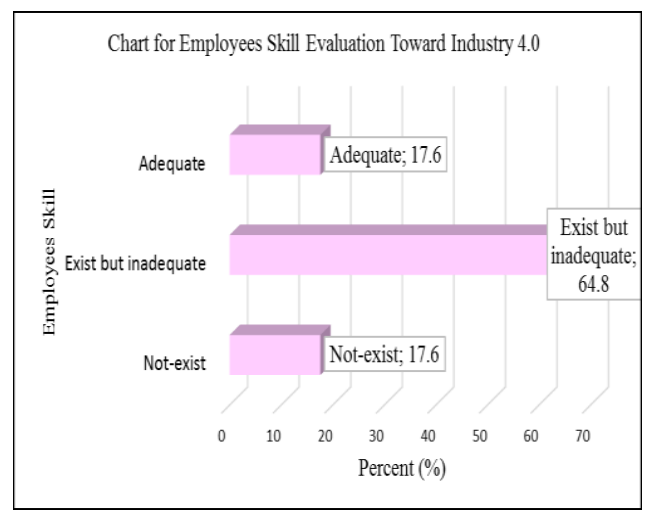

Figure 15. Existence of Skilled Workers in the Companies

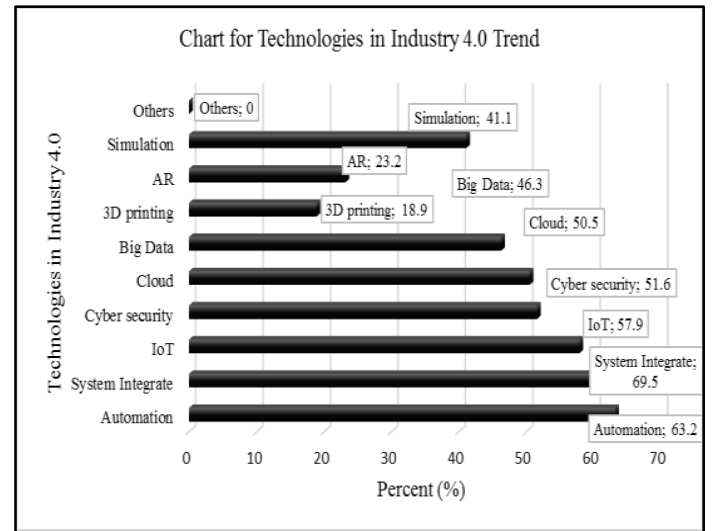

Figure 16. Future Technologies for Implementing Industry 4.0

On the other hand, digitalization for a smart manufacturing needs better technical skills in the production departments like purchase, warehouse, and logistics. The novel processes using new technological infrastructure could be very challenging for the existing workers as they have to be trained in order to handle the new applications. $17.6 \%$ of respondents stated that their companies did not possess any skilled and expert workers. A majority of the Malaysian companies (80\%) employ cheap and foreign labour instead of investing in the novel digital technologies and high-skilled workforce (Rubaneswaran, 2017). Due to a shortage of talented workers, complicated customer relationships, and a fast business pace, the success of the company relies on the competency of its workers (United Parcel Service America, 2016). For the future development of the Malaysian industries, the companies have to pay a lot of attention for developing competent employees and also recruiting a more sophisticated and digital workforce. With regards to the technologies that must be implemented for Industry 4.0 guidelines, the researchers asked the respondents to select the technologies that would increase the company productivity and improve their performance. Some companies have already implemented a few of these novel technologies as a future investment.

Figure 17 shows the different technologies selected by the respondents. As shown, $69.5 \%$ of respondents selected a vertical and horizontal integration system to be the most efficient technology that would improve the company's performance. This system comprises of universal data-integration networks which interconnect the employees in the different departments and company.

This horizontal integration system helps in a proper communication between the different production systems present in the organization (Anderl, 2015) whereas a vertical integration system involves the CPPS which 
enables the plants to rapidly respond to the changes in the demand, stock levels and the rising faults (Schlaepfer, 2015). 63.2\% of respondents selected automation robot and machine technology as the next most popular technology. Though robots cannot replace the human workforce completely, they can be of assistance to the people (Bahrin et al., 2016) for increasing the productivity. The robots can easily carry out repetitive tasks efficiently, speedily and reliably (Gilchrist, 2016). 57.9\% of respondents selected the loT technology system as the 3rd most popular technology. loT helps in accelerating the mobile opportunities and helps in developing interaction between the people and the numerous tools (International Controller Association, 2015). loT systems can ensure a better interaction between the people, equipment and the machines and move the company towards a more intelligent manufacturing. 51.6\% respondents selected the cybersecurity system the next popular technology since the loT systems, services, data and humans could open new avenues for industrial espionage, data theft, or hacking attacks (Schlaepfer et al., 2015). All companies have to tailor the risk management systems and establish a security strategy for ensuring cybersecurity and a prevention of cyber-attacks All companies have to tailor the risk management systems and establish a security strategy for ensuring cybersecurity and a prevention of cyber-attacks. Also, the cloud computing could act as the search platform and the technology ensures a more effective performance (Zhou et al., 2015). 50.5\% respondents selected a cloud system for data sharing across all sites and beyond company boundaries.

Currently, many companies have to face problems associated with higher number of data sources, a slump in the IT storage capacity and increasing number of computational resources. Therefore, research is being carried out for designing big data systems for production planning, sales prediction and clustering (Cohen et al., 2009; Niesen et al., 2016). Big data systems gather and evaluate huge amounts of data from the source and transmit it to the customer, and this technology was selected by $46.3 \%$ respondents. $41.1 \%$ people selected simulation as a computer modelling program. Simulation provides an advantage to the real-time data as it mirrors the physical world and creates a virtual model that includes machines, products and people (Bahrin et al., 2016). This could help the employees to optimize the machinery settings for developing the next product in the production line in this virtual model before actually implementing the changes in the physical setting. $18.9 \%$ people selected 3D printing, while 23.2\% people selected the Augmented Reality (AR) technology. However, both of these techniques have not received sufficient attention from the people. 3D printing is a huge technology as it can be used for rapid prototyping, construction and in architecture. This technique ensures the production of many sizes of the customized product since it requires a change in only its base software template file. Such an additive manufacturing technology requires a higher initial investment (Schlaepfer, 2015). The AR technology is integrated into the computer graphics, which enables the user to view his current environment (Paelke, 2014). Users must access and interact with the information having a direct spatial relationship with their existing environment (Paelke, 2014). The common AR technology is the Google Glass (Gilchrist, 2016), and the cost of a single device is approximately RM6000 (US\$1500).

\subsubsection{Malaysia's Efforts Toward Implementing Industry 4.0}

The Malaysian Minister of the Ministry of International Trade and Industry (MITI), has stated that the Industry 4.0 guidelines were important for boosting the economic and industrial growth of the country and ensure that the Malaysian economy reached a target of RM 2 trillion within 7-8 years, as was desired by the Malaysian Prime Minister (Malaysia Digest, 2017). MITI has stated that in September 2016, there were 235 projects, worth RM11.5 billion, under implementation in Malaysia, with a total grant of RM995.8 million. These grants included the capitalization grant worth RM548.2 and the grant of RM47.5 million for licensing and for purchasing new technologies. The direct and indirect tax incentives in Malaysia have been presented in the Income Tax Act 1967, Customs Act 1967, Sales Tax Act 1972, Excise Act 1976, Promotion of Investments Act, 1986, and the Free Zones Act 1990. All of these acts cover the investments in the R\&D and manufacturing sectors along with the environmental protection activities (MIDA, 2017). Furthermore, the Malaysian government always welcomes new proposals which facilitate the manufacturers in automating their companies and the Industry 4.0 guidelines have been included in the tax incentives (Ahmad, 2016).

The Malaysian government has provided several incentives to the industrial sector like:

i. Major incentives to the manufacturing companies

ii. Better incentives for novel technologies

iii. Incentives for better strategic projects

iv. Incentives for the SMEs

v. Incentives for investing in the selected industries

vi. Incentives for the automotive industry

vii. Incentives for utilisation of the palm oil biomass

viii. Incentives to the manufacturing sector 
Malaysian Treasury Secretary, launched the Digital Hub, which collaborated with the MITI, Malaysia Digital Economy Corporation and the private sectors for structuring the digital hub with regards to the tax incentives and involved many big data and cloud service companies (Awani, 2017). The direct tax incentive grant was partial from the payment of the income tax for specific time duration whereas the indirect tax incentives were exempted from the sales tax, import and the excise duties. In order to keep pace with the rapidly occurring transformation in the Manufacturing sector, Malaysia needs to progress further and hence a study, titled, 'Future of Manufacturing in Malaysia' was launched. The trend between the Malaysian industries was analyzed by collaborating with the Malaysian Investment Development Authority (MIDA), University of Malaya (UM) and the Universiti Teknikal Malaysia Melaka (UTeM) (MIDA, 2017), The constant growth in the Malaysian manufacturing sector was based on the implementation of smart technologies and processes. The Ministry Of Science, Technology and Innovation (MOSTI) and MITI must focus on utilizing the existing collaborative R\&D studies that review the constraints and recommend the efficient usage which would lead the effective implementation of a future smart manufacturing (Economic Planning Unit Prime's Minister, 2017). The Scientific and Industrial Research Institute of Malaysia (SIRIM) recommended the Malaysian government to carry out and coordinate the research studies, and utilize the knowledge developed by the Collaborative Research in Engineering, Science and Technology (CREST). A Memorandum of Understanding (MoU) was signed between the MIDA and the Rockwell Institute, a US-based industrial automation and a smart technology provider. This MoU was signed for promoting the exchange of the technical knowledge and the marketing strategies between the investors. The Rockwell Institute developed smart manufacturing for the HP, Pentamaster, and Muehlbauer industries in Malaysia. Such collaboration would be mutually beneficial to the relevant Malaysian stakeholders. MITI acted as a catalyst which promoted the smart manufacturing agenda and the Industry 4.0 guidelines (MIDA, 2017). This collaboration would help Malaysia to explore different avenues for grooming the local organisations which aimed to improve their competitiveness, organize outreach programs and establish smarter manufacturing units in the MIDA. According to terms of the MoU, Penang would secure approximately RM5 billion in the form of investment in the MNCs, especially the electronic-based manufacturing industries. The Penang International Technology Park present in the Batu Kawan region along with the Business Process Outsourcing (BPO) project, in Bayan Baru, implemented in collaboration with the Temasek Holdings and Economic Development Innovations, Singapore would be completed within 5-10 years. These projects would generate RM11.3 billion in a GDP value and give rise to around 25000-30000 jobs.

Furthermore, Johor Corporation (Jcrop) along with MIDA have expressed an interest in utilising the Chinese experience with regards to robotics which would help in establishing a robotic hub, called as the Robotics Future City, in Johor Bharu (Othman, 2017). This proposal would include a regional base of a Chinese company, all equipment and a production plant for manufacturing the components, a service centre for the industries and an R\&D center. Furthermore, a MoU with the Jing An Shangri La was also signed between a Chinese organization and the Malaysian entities. According to this proposal, a robotic hub costing RM15 billion would be developed in Johor. This project is expected to generate $>1000$ jobs and would provide an expert advice (Othman, 2017). The Malaysian SMEs are not generally aggressive since they only employ people with moderate talents (Economic Planning Unit Prime's Minister Department, 2017). The SME firms can be productive if they collaborate with the MNCs and implement innovative and capital-concentrated activities. The major market share was dominated by the MNCs and the national companies which comprised of the trained human resources along with the research infrastructure. In order to ensure a good performance, the SMEs provide a specialty manufacturing and support services to the national companies and the MNCs. MITI has been developed under the Vendor Development Program (VDP) for the development of the SMEs (Economic Planning Unit Prime's Minister Department, 2017). In order to include many struggling institutions, the legislature has provided a 2fold assessment program for the operational consumptions. A help provided to the boondocks enterprises ensured that they were seen as an important part of an organization. Dato Mazlan Abbas, the co-Founder and the CEO of Favoriot Sdn Bhd, stated that a majority of the Malaysian SMEs wish to stay relevant and compete with one another and hence must implement the cyber-physical technologies like automation, loT and the Big Data Analytics. Due to the higher costs of the resources and a challenging economic scenario, the SMEs remain sustainable by reducing their operational costs and increasing productivity (Abbas, 2017). He stated that these SMEs were smaller than those in the city and implementation would be less risky and ensure a better control.

Malaysia must become more ready to utilize the human capital in the new pattern for managing and garnering more interest in the country. Many of the activities must be geared towards including the private organization, like, KnowledgeCom, a native IT organization that provides innovative knowledge for converting the companies with Industry 3.0 to the Industry 4.0 guidelines. This would improve the current capacities and provide a competitive workforce after this institute collaborates with the 7 states and accepts the help provided by the Federal government for opening the Centre of Excellence Training (CoET) in Selangor, Kuala Lumpur, Johor, Perak, Penang, Sabah and Sarawak (Bernama, 2017). With such a coordinated effort, this institute aims to prepare and develop the skills of 3,300 Industry 4.0 certificated Malaysian labourers under the CoET program 
by 2018. Datuk Seri Idris Jusoh, who is the Higher Education Minister, stated that several engineering courses at the public universities would be redesigned for reflecting the current industrial requirements. These courses include chemical, civil, and electrical engineering along with the new biomedical and other hybrid engineering courses. Some the new courses would also be introduced like Virtual Reality, AR and the Artificial Intelligence (Spykerman, 2017). According to the 2u2i program, the undergraduate students must study on the campus for 2 years before joining the internship programs for another 2 years. This program was developed when the industry heads conducted lectures at the public universities and collaborated with the ministers for the specific industries.

\section{Conclusion and Future Works}

Here, the researchers have highlighted the significance of the 4 th industrial revolution. They have also stated that this concept would empower the manufacturing sector and improve their productivity. A survey was conducted for assessing the awareness levels of the managers and the employees regarding the concepts and existence of the Industry 4.0 guidelines in the Malaysian manufacturing sector. The employees and managers from many different sectors like national companies, MNCs, GLCs, and SMEs were included in this survey. But there is a space to know what kinds of companies or sectors leading the implementation of Industry 4.0 in the future. A demographic analysis of the collected data showed that many Malaysian employees and industry owners were aware of the Industry 4.0 guidelines. However, these results would be subjective and cannot explain the effect of the company's ownership towards the awareness levels of the Industry 4.0 concept. According to the survey results, while $50.5 \%$ of the people were aware of the Industry 4.0 concept, $49.5 \%$ people were not familiar or aware of this concept. The data analysis showed that the managerial familiarity and awareness about the Industry 4.0 concepts were based on the type of company sector, whether they belonged to the national or multinational companies. The MNCs possessed large assets in the form of advanced technologies which increased the productivity levels, especially in the electrical and the electronics sector. Furthermore, the researchers identified 6-dimension factors that could digitalize the companies and ensure that they were benefitted after implementing the exponential technologies. These included: strategy and organization, smart factories, smart operations, smart products, data-driven services, and smarter employees. This finding can be very helpful for all future studies and would help in establishing a future model framework that could promote the Industry 4.0 guidelines amongst the Malaysian manufacturing sectors.

\section{Acknowledgment}

The authors would like to thank the Fakulti Kejuruteraan Pembuatan, Universiti Teknikal Malaysia Melaka (UTeM) and Ministry of Education, Malaysia.

\section{References}

1. Abbas, M. (2017). Will Industry 4.0 Be the Key Success Factor for IoT in Malaysia?. [Online] Available at: https://www.linkedin.com/pulse/industry-40-key-success-factor-iot-malaysia-drmazlan-abbas [Accessed 10-July-2018].

2. Ahmad, I. A. (2016). "Is it The Dawn of Industrial Revolution 4.0 in Malaysia," My Foresight, pp. 4-7.

3. Almada-Lobo, F. (2015)." The Industry 4.0 revolution and the future of manufacturing execution systems (MES)," Journal of Innovation Management, vol.3, no. 4, pp.16-21.

4. Anderl, R. (2015). "Industrie 4.0 - Technological approaches, use cases, and implementation," Automatisierungstechnik, vol. 63, No. 10, pp. 753-765.

5. Awani, A. (2017). Malaysia Digital Hub to be launched in March 2017. [Online] Available at: http://english.astroawani.com/business-news/malaysia-digital-hub-belaunched-march-129387 [Accessed 15 August 2018].

6. Bahrin, M. A. K. , Othman, M.F. , Azli N. N. and Talib M. F. (2016). "Industry 4.0: A review on industrial automation and robotic," Jurnal Teknologi., vol. 78, no. 6-13, pp.137-143.

7. Bennett, D. (2014). “Future challenges for manufacturing," Journal of Manufacturing Technology Management, vol. 25, no. 1, pp. 2-6.

8. Bernama. (2017). Malaysia Will Trail Behind If It Ignores Industry 4.0. [Online] Available at: http://www.themalaysiantimes.com.my/malaysia-will-trail-behind-if-it-ignores-industry-4-0/ [Accessed 18-Aug-2018]. 
9. Cohen, J., Dolan, B., Dunlap, M., Hellerstein, J. and Welton, C. (2009). “MAD skills: New Analysis Practices for Big Data, " Proceedings of the VLDB Endowment, vol. 2, no. 2, pp. 1481-1492.

10. Economic Planning Unit Prime’s Minister Department. (2017). Small \& Medium Enterprise (SMEs) [Online]. Available at: http://www.epu.gov.my/en/development-policies/small-mediumenterprise. [Accessed 1-Aug-2018].

11. Federation of Malaysian Manufacturers. (2017). Registered Manufacturer in Malaysia. [Online] Available at : http://www.fmm.org.my/ [Accessed 18-July 2018].

12. Fiwaremexico. (2017). The challenges and opportunities of Industry 4.0 for Mexico manufacturing. [Online]. Available at: http://www.fiwaremexico.org/the-challenges-andopportunities-of-industry-4-0-for-mexico-manufacturing/ [Accessed 21-Aug-2018].

13. Gates, D. K. (2017). Industry 4.0: Smart products, smart processes, smart profits. [Online] Available at: https://home.kpmg.com/xx/en/home/insights/2017/04/industry-4-0-smartproducts-smart-processes-smart-profits.html [Accessed 20-Jun-2018].

14. German Malaysian Institute (GMI). (2015). Industry 4.0 Seminar. [Online] Available at: http: / /www.gmi.edu.my/index.php?cat=172 [Accessed 29-July-2018].

15. Gilchrist, A. (2016). Industry 4.0: The Industrial Internet of Things, Bangken, New York: Apress.

16. Goericke, D., Lichtblau, K. and Volker, S. (2017). Industry 4.0 Readiness Online Self-Check for Businesses, German Engineering Federation (VDMA) [Online] Available at : https: / / www.industrie40-readiness.de/?lang=en [Accessed 20-Aug-2018].

17. Hermann, M., Pentek, T. and Otto, B. (2016). "Design Principles for Industrie 4.0 Scenarios,". The 49th Hawaii International Conference on System Sciences (HICSS), Koloa, HI, pp. 3928-3937.

18. International Controller Association. (2015). Controlling in the Age of Intelligent Networks Dream Car of the Dream Factory of the ICV 2015. [Online] Available at: https://www.icvcontrolling.com/fileadmin/Assets/Content/AK/Ideenwerkstatt/Files/Dream_Car_Industrie_4.0 _EN.pdf. [Accessed 17-July-2018].

19. Kagermann, H., Helbig, J., Hellinger, A. and Wahlster, W. (2013). "Recommendations for implementing the strategic initiative industrie 4.0: Securing the future of german manufacturing industry," Acatech, Germany.

20. Klimoski, R. (2016). "Critical success factors for cybersecurity leaders: Not just technical competence," People and Strategy, 39(1), p.14.

21. Kumar, V. Chattaraman, V., Neghina, C. , Skiera, B. , Aksoy, L. , Buoye, A. and Henseler, J. (2013). "Data-driven services marketing in a connected world," Journal of Service Management, vol 24, no. 3, pp. 330-352.

22. Malaysian Digest. (2017). MITI Gearing Up to Face Industry 4.0 [Online] Available at: http: / / www.malaysiandigest.com/business/652701-miti-gearing-up-to-face-industry-4-0.html [Accessed 10 Jun 2018].

23. Malaysian Investment Development Authority (MIDA). (2017). Incentives in Manufacturing Sector. [Online] Available at: http://www.mida.gov.my/home/incentives-in-manufacturingsector/posts/ [Accessed 10 July 2018].

24. Ministry of International Trade and Industry (MITI). (2017). Industry 4.0 Workshop - Embracing the Future of Manufacturing. [Online] Available at: http://www.mida.gov.my/home/eventdetails/164/ [Accessed 15-July-2018].

25. Niesen, T., Houy, C., Fettke, P. and Loos, P. (2016). “Towards an Integrative Big Data Analysis Framework for Data-Driven Risk Management in Industry 4.0," in 49th Hawaii International Conference on System Sciences (HICSS), Koloa, HI, pp. 5065-5074.

26. Othman, A. F. (2017). Malaysia Turns to China on First Foray into Robotics. [Online] Available at: https://www.nst.com.my/news/nation/2017/04/230309/malaysia-turns-china-first-forayrobotics [Accessed 13 April 2018].

27. Othman, A. F. (2017). MoU Signed To Study Development for RM15 billion Johor Robotics Hub. [Online] Available at: https://www.nst.com.my/news/nation/2017/04/230488/mou-signedstudy-development-rm15-billion-johor-robotics-hub [Accessed 2-Jun-2018]. 
28. Paelke, V. (2014). "Augmented reality in the smart factory: Supporting workers in an industry 4.0. environment," Proceedings of the 2014 IEEE Emerging Technology and Factory Automation (ETFA), Barcelona, pp. 1-4.

29. Ramstetter, E. D. and Shahrazat, A. (2009). Foreign Multinationals in Malaysian Manufacturing After the Crisis. [Online] Avaiable at: http://www.agi.or.jp/7publication/workingpp/wp2009/2009-13.pdf [Accessed 16-Aug-2018].

30. Pan, M., Sikorsi, J., Kastner, C. A. , Akroyd, J., Mosbach, S., Lau, R. and Kraft, M. (2015). "Applying industry 4.0 to the Jurong island Eco-industrial park," Energy Procedia., vol. 75, pp. 1536-1541.

31. Rubaneswaran. (2017). Malaysia Akan Ketinggalan Jika Abaikan Industri 4.0. Astro Awani. [Online] Available at: http: / /www. astroawani.com/berita-malaysia/malaysia-akan-ketinggalanjika-abaikan-industri-4-0-128119 [Accessed 15-July-2018].

32. Schlaepfer, R. C., Koch, M. and Merkofer, P. (2015). Industry 4.0. Challenges and solutions for the digital transformation and use of exponential technologies. [Online] Available at: https://www2.deloitte.com/content/dam/Deloitte/ch/Documents/manufacturing/ch-enmanufacturing-industry-4-0-24102014.pdf [Accessed 13-July-2018].

33. Schlechtendahl, J., Keinert, F., Kretschmer, M., Lechler, A. and Verl, A. (2014) "Making existing production systems Industry 4.0-ready," Production Engineering, vol. 9, no. 1, pp. 143-148.

34. Spykerman, N. (2017). Redesigning Engineering Courses. [Online] Available at: http://www.thestar.com.my/news/education/2017/05/28/redesigning-engineering-courses/ [Accessed 20-July-2018].

35. Star, T. (2017). Taking on opportunities of industry 4.0 [Online]. Available at: http: / /www.thestar.com.my/metro/smebiz/news/2017/04/17/taking-on-opportunities-ofindustry-40/ [Accessed 2-Jun-2018].

36. United Parcel Service America. (2016). The Rise of Smart Operations : Smart Operations Will Be Critical To Future Success. [Online] Available at:https://solvers.ups.com/assets/UPS16024_SmartOps_WP_p2.pdf [Accessed 18- Aug-2018].

37. Unknown. (2016). Rancangan Malaysia Kesebelas (2016-2020). [Online] Available at : http://epu.gov.my/sites/default/files/Bab1.pdf [Accessed 31-July-2018].

38. Vouzas, F. and Psychogios, A. G. (2007). "Assessing managers' awareness of TQM," The TQM Magazine, vol 9. no. 1, pp. 62-75.

39. Wan, J., Cai, H. and Zhou, K. (2015). "Industrie 4.0: Enabling technologies," The Proceedings of 2015 International Conference on Intelligent Computing and Internet of Things, Harbin, pp.135140.

40. Waslo, R., Lewis,T., Hajj, R. and Carton, R. (2017). Industry 4.0 and cybersecurity: Managing risk in an age of connected production. Deloitte University Press. [Online] Available at: https://www2.deloitte.com/content/dam/Deloitte/tr/Documents/risk/industry4-0cybersecurity.pdf [Accessed 22-Aug-2018].

41. Wolf, C., Dalal, S., DaVanzo, J., Larson, E. V., Akhmedjonov, A., Dogo, H., Huang, M. and Montoya, S. (2011). "China and India, 2025: a comparative assessment," Santa Monica, CA, Monograph MG1009.

42. Zhou, K., Liu, T. and Zhou, L. (2015). "Industry 4.0: Towards future industrial opportunities and challenges," 12th International Conference on Fuzzy Systems and Knowledge Discovery (FSKD), Zhangjiajie, pp. 2147-2152. 